JUURNAL

of Health Inequalities

\title{
The 2019 Oral, Head and Neck Cancer Awareness Week in light of the history of research on laryngeal cancer at the Otolaryngology, Head and Neck Surgery Department of Wrocław University Hospital
}

\author{
Michał Zatoński', Natalia Kucharczyk' ${ }^{1}$ Katarzyna Naglik', Ewelina Bobak-Sarnowska² ${ }^{2}$ Olga Fedorowicz ${ }^{3,4}$, \\ Monika Kowalska³, Tomasz Zatoński² \\ 'Wroclaw Medical University, Poland \\ 2Department and Clinic of Otolaryngology, Head and Neck Surgery, Wroclaw Medical University, Poland \\ ${ }^{3}$ University Clinical Hospital in Wroclaw, Poland \\ ${ }^{4}$ Department of Clinical Pharmacology, Wroclaw Medical University, Poland
}

\begin{abstract}
The Otolaryngology, Head and Neck Surgery Department of Wrocław University Hospital has a history of research and treatment of laryngeal cancer spanning over 40 years. In response to the rapid growth in cancer occurrence, morbidity, and mortality, and in particular head and neck cancers, after the Second World War Polish doctors developed numerous programmes and established facilities dedicated to tackling this problem. Professor Stanisław Iwankiewicz, the rector of Wrocław Medical University in the 1970 s and the director its Department of Laryngology, played a major role in the development of laryngeal cancer diagnosis and treatment methods in Poland.

Building on its historical role in cancer research, treatment, and prevention, the Department of Otolaryngology, Head and Neck Surgery of Wrocław Medical University continues to participate and lead on numerous programmes in this area. In 2019, the department participated in the Oral, Head, and Neck Cancer Awareness Week. This study analysed data from 27 patients ( 15 male, 12 female), who completed the Patient Concerns Inventory (PCI) questionnaire and were consulted by ear-nose-thorat (ENT) specialists. Results confirm the usefulness of the PCI questionnaire and emphasise the importance of education in strengthening the prevention of head and neck neoplasms.
\end{abstract}

KEY WORDS: head and neck cancer, patient concerns inventory, PCI, head and neck cancer prevention.

ADDRESS FOR CORRESPONDENCE: Michał Zatoński, Wrocław Medical University, 38 Cesarzowicka St., 52-408 Wrocław, Poland, e-mail: michal.zatonski@gmail.com

\section{INTRODUCTION}

Head and neck cancer is a collective name for all of the cancers located in the head and neck area except the brain and eyeball. They may occur in various locations and comprise upper aerodigestive tract anatomic sites. They represent the third most common cause of cancer death worldwide. A 2018 analysis estimated 550,000 head and neck cancer cases worldwide and over 330,000 deaths from the disease yearly $[1,2]$. Data from the Nationwide
Head and Neck Cancer Prevention Programme indicate that peak morbidity occurs in patients between 55 and 64 years old. Among patients suffering from head and neck cancer, $60 \%$ seek medical attention too late, in III and IV clinical stages of cancer. The majority of them die within five years from diagnosis [3].

The development of head and neck cancer is the result of the interaction between environmental factors and genetic inheritance and is, therefore, multifactorial. Smoking and 
alcohol consumption are the leading risk factors for the development of this disease [2]. However, in the last decade increased incidence of throat, larynx, tongue, and salivary gland carcinoma was observed among young people, under 40 years old, who are nonsmokers and not extensive alcohol consumers [3]. Epidemiological studies indicate a close relationship between the development of middle throat tumors (palatine tonsil, the root of the tongue) and human papillomavirus infection, which is transmitted sexually, and which is the main risk factor in young adults [4]. As reviewed by Galbiatti et al., symptoms of head and neck cancer are often confused with symptoms that occur in colds. They consist of: tongue pain, untreated mouth ulcers, white and red spots on the tongue, sore throat, persistent hoarseness, problems with swallowing, neck tumor, one side stuffed nose, and bleeding from the nose [5]. Due to the "1 for 3 Scheme", which reveals risk factors related to head and neck cancer, in case of the persistence of one of these symptoms for longer than three weeks a general practitioner should direct the patient to a laryngologist. Early diagnosis and non-invasive treatment allow $95 \%$ of patients to return to work with a good quality of life [6].

\section{LARYNGEAL CANCER IN POLAND}

After the Second World War, the Polish population experienced a dramatic increase in the rates of head and neck cancer, especially laryngeal cancer morbidity and mortality. Laryngeal cancer became one of the most frequent malignant neoplasms in the world. The main reason for it was a dramatic increase in tobacco and alcohol consumption after 1945 [7, 8]. In response, the Polish Government asked the Radium Institute (which was created by Maria Curie Skłodowska in 1932) to prepare a National Cancer Control Program. In the 1970s the Polish government built in Warsaw a Comprehensive Oncological Center, which consisted of basic cancer studies departments, departments for cancer registration and epidemiology, as well as departments for primary and secondary cancer prevention. The main part of the Center was the 700 beds strong oncological hospital. This hospital was organised according to human topography and specific organs. For example, in the Head and Neck Department, there were doctors specialized in laryngology, radiotherapy, chemotherapy, surgery etc. This allowed a comprehensive approach to diagnostics, treatment, and rehabilitation from different cancers [8].

The epidemiological part of the Comprehensive Cancer Control Program in Poland - PR7 - was formulated under the leadership of one of the directors of Cancer Institute, Professor Tadeusz Koszarowski, in collaboration with WHO International Agency for Research on Cancer in Lyon (IARC). Dr. Calum Muir, the former epidemiological director of IARC, advised that one of the first research fields of cancer epidemiology in Poland should be laryngeal cancer. This was in relation to the dramatic increase of laryngeal cancer morbidity and mortality in the male population in Poland at the time [9-14].
In the early 1980s, Dr. Witold Zatoński was invited and employed by prof. Tadeusz Koszarowski to coordinate the PR7 program in the field of cancer etiology, cancer registration and epidemiology, and primary and secondary cancer prevention. He in turn invited Profesor Stanisław Iwankiewicz, a pioneer of laryngeal cancer research in Poland, the rector of Wrocław Medical University, and the director of its Department of Laryngology, to join the collaboration on one of the most crucial parts of the PR7 program by taking the lead on a laryngeal cancer control national project. Finally, Prof. Stanisław Iwankiewicz invited two other outstanding Polish ENT (Ear, Nose, Throat) groups led by prof. Jan Kuś from the Department of Head and Neck Surgery of CMKP (Medical Center for Postgraduate Education) in Warsaw [9] and prof. Tatiana Gierek, from the Department of Head and Neck Surgery of the Silesian Medical University to join this project [15]. Prof. Iwankiewicz has established a group of researchers led by Dr. Irena Baran and consisting of two outstanding ENT physicians Dr. Jerzy Rak and Dr. Dariusz Zatoński. The first achievement of this group was the organization of a registry of laryngeal cancer for the district of Lower Silesia. At this time it was one of the first population-based laryngeal cancer registries in Europe. The registry's database was developed in collaboration with the Wrockaw Technical University and Wrocław Computer Factory - it was one of the few international cancer registries to be digitalized at the time $[9,16,17]$.

The project has laid the groundwork for all the laryngeal cancer research in Poland and was accompanied by a series of high-quality scientific publications. Prof. Iwankiewicz's work led to the establishment of proven tools to study, diagnose, prevent and treat laryngeal cancer. The team also conducted the very first case-controlled population-based study in Poland using the population of Lower Silesia as a control sample. Among other papers, they were a base for many $\mathrm{PhD}$ theses [18-30].

Having in mind this pioneer history of larynx cancer research, the Wrocław Medical University has been a epidemiological and oncological science hub for nearly forty years now. It led numerous important laryngeal cancer studies which resulted in internationally published and acclaimed papers. Today under the Leadership of prof. Tomasz Zatoński the Department of Laryngology, Head and Neck Surgery at Wrocław Medical University remains one of the leading Polish laryngeal research centers [31].

The team present at the Department of Otolaryngology, Head and Neck Surgery of Wrocław Medical University is continuing the grounbreaking historical work. One of such recent endeavours was the 2019 Oral, Head and Neck Cancer Awareness Week, the results of which are discussed in this article [6].

\section{MATERIAL AND METHODS}

Oral, Head and Neck Cancer Awareness Week, led by the Head and Neck Cancer Alliance is a weeklong 


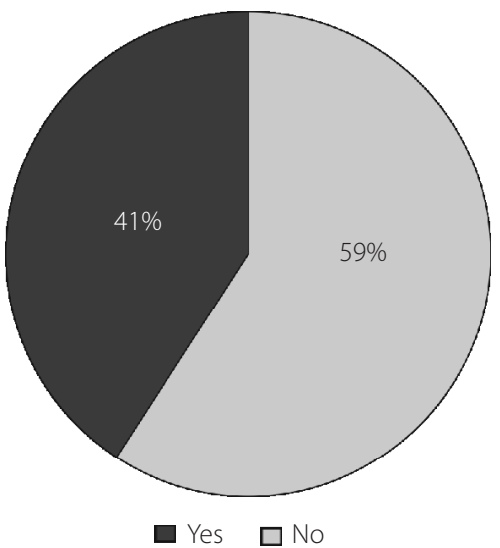

FIGURE 1. Do you smoke cigarettes?

series of events promoting awareness of oral, head, and neck cancer, accompanied by a day of free cancer screenings. Wrocław University hospital has participated in the program by preparing meetings, presentations and inviting patients for the screenings in September 2019 at the Head and Neck Surgery Department. During that week 37 people presented to the University Clinical Hospital in Wroclaw. As a result of the interview and initial survey, ten people (six women and four men) were excluded from the screening due to a lack of risk factors. Twenty-seven people, 12 women, and 15 men qualified for further laryngological consultation.

During the ENT consultation, subjects filled out a Patient Concerns Inventory (PCI) questionnaire, which assessed the physical and functional well-being, social, mental, and emotional health problems. The patient could select several problems that he wanted to discuss during the visit. The survey has been translated into Polish. and validated in the experimental group. PCI questionnaire was designed in the University of Washington and is known as UW-QOLv4 [32]. Polish version of the UW-QoLv4 questionnaire seems to have been translated well, is valid, and is valuable for the assessment of the quality of life among Polish patients with cancers of the head and neck [33]. PCI is a way of alerting clinical teams as to which patients need additional support [34]. In this programme the paper version of the PCI questionnaire was used and then a database containing the answers of patients was created.

\section{RESULTS}

Social interviews of patients reported twenty-six people with secondary education, seven people with higher education, two people with a bachelor's degree, one person with matriculation and basic vocational education.

TABLE 1. Age (years) and sex of the respondents

\begin{tabular}{|l|c|c|}
\hline & Females & Males \\
\hline Mean (SD) & $68.0(7.7)$ & $50.2(16.0)$ \\
\hline Min-Max & $58-84$ & $21-67$ \\
\hline
\end{tabular}

$S D$-standard deviation
Twelve people worked non-manually, five manually and twenty did not work.

Patients reported learning about the head and neck cancer prevention initiative from the media $-46 \%$, from their primary care physician $-13 \%$ and from other sources $-41 \%$.

The most common symptoms reported are hoarseness (43\% of people) and burning in the throat and mouth pain (35\%). Fifteen people reported bleeding during brushing their teeth. Thirteen respondents felt an unpleasant smell from their mouths. The feeling of dry mouth is reported by ten people. One person reported complaints such as spontaneous bleeding when speaking or eating, increased tooth mobility and swollen gums. $46 \%$ of the respondents have dentures.

Fifteen people reported to be smokers, three people quit smoking and six smoke e-cigarettes. The second carcinogen is alcohol consumption. Forty-six percent of those surveyed do not drink alcohol, and fifty-four percent drink occasionally (20 people). Fifty-seven percent of people had a history of cancer in the family. Four people had cancer themselves, including one in the head and neck.

Respondents visit the dentist at various frequencies: ten people every six months, fifteen people once a year, eleven less than once a year, and one person did not answer. The frequency of brushing teeth varies more: $68 \%$ of respondents brush their teeth twice a day, three and more times a day $-24 \%$ and only once a time $-8 \%$.

The patients were aged between $21-84$ years old. The study sample characteristics are summarized in Table 1.

Symptoms that led to a visit during the prevention program are hoarseness (60\%), burning in the mouth (45\%), swallowing problems (20\%), and other (30\%). Ten people smoke cigarettes, one quit smoking about fifty years ago. Three respondents drink alcohol one to two times a week, five occasionally and twelve people declare that they do not consume alcohol at all. To the question about the number of life sexual partners, the respondents answered: up to three (80\%), from three to seven (10\%), above seven (5\%) and 5\% did not answer the question. Thirteen people in the family had cancer, including two in the head and neck. Two qualified people had cancer, including one with head and neck cancer.

During the visit, subjects filled out a PCI questionnaire, which assessed the physical and functional well-being, social, mental and emotional health problems. The answers are presented in the Table 2.

The biggest concern on the part of respondents was pain in the neck and head area (40\% of patients). Other factors are: phlegm (35\%), dry mouth (25\%), swallowing $(25 \%)$, cough (25\%), breathing (20\%), fatigue $(20 \%)$ and sleeping (20\%). Other issues that patients wanted to talk about were: intestinal problems (like a bowel and a diarhoea constipation - 15\%), shoulder (also 15\%) and depression (10\%), deal (10\%), swelling (10\%) and hearing (10\%). All concerns that patients wanted to raise during the ENT visit were presented in Figures 1 and 2. 
TABLE 2. Survey responses to the questions in the Patient Concerns Inventory (PCI) questionnaire regarding physical, functional, social, mental, emotional and spiritual well-being

\begin{tabular}{|c|c|c|c|}
\hline & & Yes & No \\
\hline \multirow{29}{*}{$\begin{array}{l}\text { Physical and functional } \\
\text { well-being }\end{array}$} & Activity & $0(0 \%)$ & $20(100 \%)$ \\
\hline & Appetite & $0(0 \%)$ & $20(100 \%)$ \\
\hline & Bowel-diarhoea constipation & $3(15 \%)$ & $17(85 \%)$ \\
\hline & Breathing & $4(20 \%)$ & $16(80 \%)$ \\
\hline & Chewing/eating & $0(0 \%)$ & $20(100 \%)$ \\
\hline & Cough & $5(25 \%)$ & $15(75 \%)$ \\
\hline & Dental health/teeth & $0(0 \%)$ & $20(100 \%)$ \\
\hline & Dry mouth & $5(25 \%)$ & $15(75 \%)$ \\
\hline & Energy levels & $0(0 \%)$ & $20(100 \%)$ \\
\hline & Fatigue/tiredness & $4(20 \%)$ & $16(80 \%)$ \\
\hline & Hearing & $2(10 \%)$ & $18(90 \%)$ \\
\hline & Indigestion & $0(0 \%)$ & $20(100 \%)$ \\
\hline & Mobility & $0(0 \%)$ & $20(100 \%)$ \\
\hline & Mouth opening & $1(5 \%)$ & $19(95 \%)$ \\
\hline & Phlegm & $7(35 \%)$ & $13(65 \%)$ \\
\hline & Nausea & $1(5 \%)$ & $19(95 \%)$ \\
\hline & Pain in head and neck & $8(40 \%)$ & $12(60 \%)$ \\
\hline & Pain elsewhere & $1(5 \%)$ & $19(95 \%)$ \\
\hline & Reflux - eat back & $1(5 \%)$ & $19(95 \%)$ \\
\hline & Salivation & $1(5 \%)$ & $19(95 \%)$ \\
\hline & Shoulder & $3(15 \%)$ & $17(85 \%)$ \\
\hline & Sleeping & $4(20 \%)$ & $16(80 \%)$ \\
\hline & Smell & $1(5 \%)$ & $19(95 \%)$ \\
\hline & Sore lips & $1(5 \%)$ & $19(95 \%)$ \\
\hline & Swallowing & $5(25 \%)$ & $15(75 \%)$ \\
\hline & Swelling & $2(10 \%)$ & $18(90 \%)$ \\
\hline & Tarse & $0(0 \%)$ & $20(100 \%)$ \\
\hline & Vomiting/sickness & $1(5 \%)$ & $19(95 \%)$ \\
\hline & Weight & $1(5 \%)$ & $19(95 \%)$ \\
\hline \multirow[t]{4}{*}{ Related to treatment } & Cancer treatment & $0(0 \%)$ & $20(100 \%)$ \\
\hline & Regret about treatment & $1(5 \%)$ & $19(95 \%)$ \\
\hline & PEG tube & $0(0 \%)$ & $20(100 \%)$ \\
\hline & Wound healing & $0(0 \%)$ & $20(100 \%)$ \\
\hline \multirow{7}{*}{$\begin{array}{l}\text { Social protection and social } \\
\text { well-being }\end{array}$} & Carer & $1(5 \%)$ & $19(95 \%)$ \\
\hline & Children & $1(5 \%)$ & $19(95 \%)$ \\
\hline & Financial benefits & $0(0 \%)$ & $20(100 \%)$ \\
\hline & Home care/district nurse & $0(0 \%)$ & $20(100 \%)$ \\
\hline & Lifestyle (smoking/alcohol) & $0(0 \%)$ & $20(100 \%)$ \\
\hline & Recreation & $0(0 \%)$ & $20(100 \%)$ \\
\hline & Relationships & $0(0 \%)$ & $20(100 \%)$ \\
\hline \multirow{14}{*}{$\begin{array}{l}\text { Mental, emotional and spiritual } \\
\text { well-being }\end{array}$} & Appearance & $0(0 \%)$ & $20(100 \%)$ \\
\hline & Angry & $1(5 \%)$ & $19(95 \%)$ \\
\hline & Anxiety & $1(5 \%)$ & $19(95 \%)$ \\
\hline & Deal & $2(10 \%)$ & $18(90 \%)$ \\
\hline & Depression & $2(10 \%)$ & $18(90 \%)$ \\
\hline & Feer of cancer coming back & $0(0 \%)$ & $20(100 \%)$ \\
\hline & Fear of adverse events & $0(0 \%)$ & $20(100 \%)$ \\
\hline & Intimacy & $0(0 \%)$ & $20(100 \%)$ \\
\hline & Memory & $1(5 \%)$ & $19(95 \%)$ \\
\hline & Mood & $0(0 \%)$ & $20(100 \%)$ \\
\hline & Self-assessment & $0(0 \%)$ & $20(100 \%)$ \\
\hline & Sex & $0(0 \%)$ & $20(100 \%)$ \\
\hline & Spiritual/religious aspects & $0(0 \%)$ & $20(100 \%)$ \\
\hline & Temperament and personality & $0(0 \%)$ & $20(100 \%)$ \\
\hline
\end{tabular}




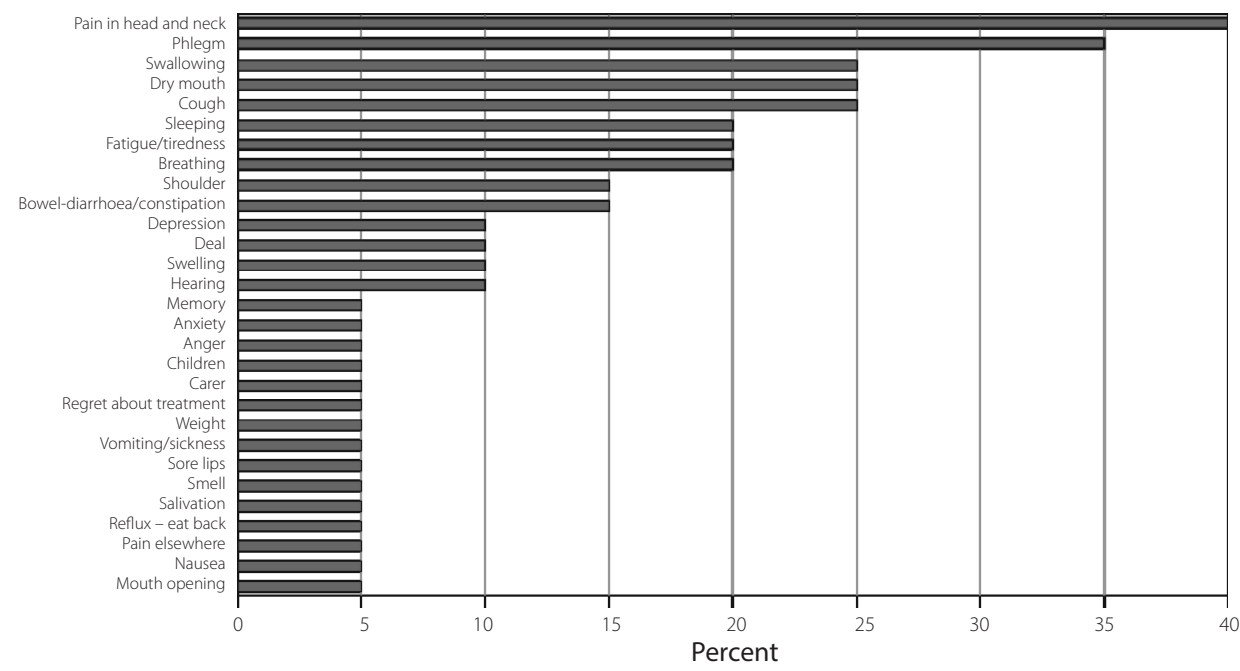

FIGURE 2. Issues from PCl that patients specyfilally wanted to talk about in their consultation whilst at Otolaryngology, Head and Neck Surgery Department in Wroclaw

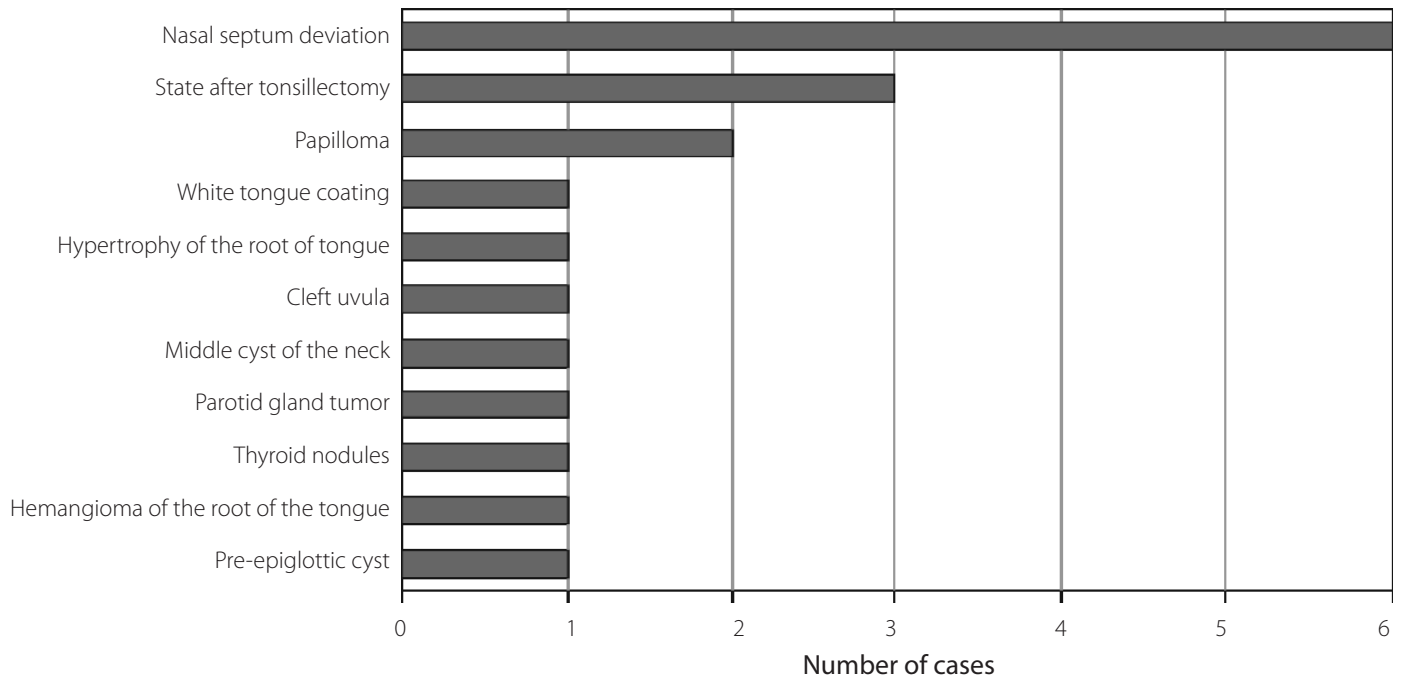

FIGURE 3. All changes noticed in the examined patients after ENT assessment

In the experimental group, there were no ear diseases. Only one person had a plug of earwax. After throat laryngological assessment it was found that three people had tonsillectomy (15\%), two had papillomas present on the palatopharyngeal arch (10\%), one person had raid in the mouth (5\%), cleft palate in the area of the tongue, hemangioma of the root tongue (5\%), pre-epiglottic cyst (5\%) and hypertrophy of the root tongue (5\%). Larynx endoscopy showed one case of vocal folds dysfunction, swelling of the interarytenoid area, hyperplasia of false vocal cords and Reinke's edema (Fig. 3).

The study has shown a middle cyst of neck, thyroid nodules, and parotid gland tumors among the surveyed patients. The salivary gland tumor imaging was sent for radiological diagnostics and then qualified for surgery in the Department of Otolaryngology.

The most common diagnosis on the assessment of the nose in this group of patients was nasal septum deviation - which was found in as many as $30 \%$ of the respondents $(n=6)$, including one with a perforated septum. Allergic mucosal edema was observed in one person. One patient was qualified and operated at the Otolaryngology Clinic, and one is under the constant supervision of a specialist.

\section{DISCUSSION}

The PCI has shown that respondents wanted to talk about symptoms that are related to head and neck cancer risk factors. Symptoms include mainly: coughing (25\%), phlegm $(35 \%)$, dry mouth $(25 \%)$, hearing $(10 \%)$, tiredness $(20 \%)$, pain in head and neck (40\%), swallowing (25\%). Despite the fact that patients reported to the Clinic with physical problems related to Head and Neck cancer genuine need for mental, emotional and spiritual support was revealed. Respondents want to talk about problems as: depression (10\%), anxiety (5\%), dealing with problems (10\%), anger (5\%), memory(5\%). These results indicate the fact that psychological support is indispensable in diagnosis and prevention of Head and Neck cancer. 
Subjects either did not notice correlation or it was not relevant for them to talk about factors as: lifestyle and habitat, indigestion, mobility, cancer treatment, PEG tube, wound healing, financial benefits, home care/ district nurse, recreation, relationships, appearance, fear of cancer coming back, fear of adverse events, intimacy, mood, self-assessment, sex, religious aspect, temperament and personality. Reluctance to provide answers could have been potentially caused by lack of access to information about cancer treatment. Superstitious beliefs and illiteracy may also be contributory factors [34].

Among experimental group cases of the following diseases were detected: papillomas on the palatopharyngeal arch (2), raid in the mouth (1), hemangioma of the roof of the tongue (1), pre-epiglottic cyst (1), hypertrophy of the roof of the tongue (1). The research shows a correlation between risk factors and presented diseases. Major risks factors include smoking and alcohol abuse.

Despite the correlation between risk factors and head and neck diseases the research shows that in some cases risk factors do not contribute to the development of the disease. As an example among the experimental group there was one patient who smoked more than 16 cigarettes per day, but the ENT study did not reveal any hypertrophic changes, only nasal septum deviation which is not associated with smoking.

\section{CONCLUSION}

The PCI questionnaire is a practical tool in Cancer Prevention Programmes. This questionnaires inform the doctor about general health issues of the patient. The research shows that the most important part of prevention is continuous education of all patients. Additionally, prophylactic tests may ensure success in oncological diagnosis and treatment.

\section{ACKNOWLEDGEMNT}

This paper is dedicated to Prof. Stanisław Iwankiewicz, one of the fathers of Polish laryngology on the $100^{\text {th }}$ anniversary of his birth.

\section{DISCLOSURE}

The authors report no conflict of interest.

\section{References}

1. Fitzmaurice C. Global, regional, and national cancer incidence, mortality, years of life lost, years lived with disability, and disability-adjusted life-years for 29 cancer groups, 2006 to 2016 : a systematic analysis for the Global Burden of Disease study. J Clin Oncol 2018; 36 (15): 1568.

2. Haddad RI, Shin DM. Recent advances in head and neck cancer. N Eng J Med 2008; 359 (11): 1143-1154.

3. Program polityki zdrowotnej. Ogólnopolski program profilaktyki pierwotnej i wczesnego wykrywania nowotworów głowy i szyi [Nationwide Head and Neck Cancer Primary Prevention and Early Detection Program]. Available from: http://zdrowie. gov.pl/zamowienia/download/dok_id/97/zal/787/type/zal/dir/ pub.html (accessed: 29 March 2021).

4. Torrente MC, Rodrigo JP, Haigentz M, et al. Human papillomavirus infections in laryngeal cancer. Head Neck 2011; 33 (4): 581-586.

5. Galbiatti ALS, Padovani-Junior JA, Maníglia JV, et al. Head and neck cancer: causes, prevention and treatment. Braz J Othorhinolaryngol 2013; 79 (2): 239-247.

6. Make Sense Campaign. About Head and Neck Cancer. Cancer Resources. Available from: https://makesensecampaign.eu/en/ cancer-information/cancer-resources/ (accessed: 29 March 2021).

7. Staszewski J. Smoking and cancer in Poland. Br J Cancer 1960; 14 (3): 419-436.

8. Zatoński W, Beker N. Atlas of Cancer Mortality in Poland 1975-1979. Springer Verlag, Heidelberg 1988.

9. Kuś J, Zatoński W, Iwankiewicz ST, et al. Projekt karty nowotworowej krtani [Laryngeal Cancer Dignosis Card]. Otolaryngol Pol 1983; 4: 156.

10. Zatoński W, Didkowska J, Gadomska H. Cancer of the larynx in Warsaw and in selected rural areas. Neoplasma 1983; 30 (3): 379-384.

11. Zatoński W, Mierzwińska J, Didkowska J. Badanie porównawcze przypadków nowotworów złośliwych krtani [A comparative study of laryngeal malignancies]. Otolaryngol Pol 1983; Suppl 3: 130.

12. Zatoński W, Didkowska J, Tarkowski W. Geografia nowotworów złośliwych krtani u mężczyzn w latach 1975-1981 w Polsce [Geography of malignant neoplasms of the larynx in men in the years 1975-1981 in Poland ]. Otolaryngol Pol 1983; Suppl 3: 138.

13. Zatoński W, Gadomska H, Abramczuk A. Nowotwory złośliwe krtani - analiza epidemiologiczna [Malignant neoplasms of the larynx. Epidemiological analysis.]. Otolaryngol Pol 1983; 7: 413.

14. Zatoński W, Didkowska J. Geograficzne różnice w umieralności na nowotwory złośliwe krtani w Polsce w latach 1970-1981 [Geographical differences in mortality of malignant laryngeal neoplasms in Poland in the years 1970-1981]. Nowotwory 1985; 35 (4): 348-354.

15. Gierek T, Bielska D, Majzel K, et al. Opracowanie analizy epidemiologicznej chorych na nowotwory złośliwe krtani hospitalizowanych w I Klinice Laryngologii Śląskiej Akademii Medycznej w Katowicach w latach 1971-1980 [An epidemiological analysis of patients with malignant neoplasms of the larynx hospitalized in the 1st Department of Laryngology of the Medical Academy of Silesia in Katowice in the years 1971-1980]. Otolaryngol Pol 1983; 1: 10.

16. Zatoński W, Marczewski A, Smolik R. Ujmowanie danych medycznych w systemie BAMED. Materiały II Krajowej Konferencji „Biocybernetyka i inżynieria biomedyczna” [Data processing medical devices in the BAMED system. Materials of the $2^{\text {nd }}$ National Conference "Biocybernetics and Biomedical Engineering"]. Gliwice 6-9.02.1978.

17. Zatoński W, Marczewski A, Smolik R. Zaprogramowany opis badania lekarskiego (ZOBL) [Computer-assisted diagnosis]. Pol Tyg Lek 1980; 35 (30): 1163-1165.

18. Baran I, Didkowska J, Iwankiewicz ST, et al. Analiza zachorowań na nowotwory złośliwe krtani na terenie Dolnego Śląska w 1981 r. [Analysis of the incidence of malignant neoplasms of the larynx in Lower Silesia in 1981]. Otolaryngol Pol 1983; 3: 147. 
19. Zatoński D. Epidemiologia nowotworów złośliwych na dolnym Śląsku w latach 1979-1981 w materiale Kliniki Otolaryngologicznej Akademii Medycznej we Wrocławiu [The epidemiology of malignant neoplasms in Lower Silesia in the years 1979-1981 in the Otolaryngology Clinic of the Medical Academy in Wrocław ]. Rozprawa doktorska [Doctoral thesis]. Wydział Lekarski Akademii Medycznej we Wrocławiu, Wrocław 1983.

20. Zatoński W, Mierzwińska J. Przeżycia chorych na nowotwory złośliwe krtani [Survival of patients with malignant neoplasms of the larynx]. Nowotwory 1987; 37 (1): 60-66.

21. Mierzwińska J, Zatoński W. Rola tytoniu w etiologii nowotworu krtani [Tobacco in the laryngeal cancer aethiology]. Streszczenia z IV Międzynarodowego Zjazdu Naukowego Polskiego Towarzystwa Lekarskiego, Poznań 27-29.06.1988.

22. Zatoński W, Mierzwińska J, Krygier M. Palenie tytoniu a nowotwory złośliwe krtani w porównawczym badaniu przypadków [Tobacco smoking and laryngeal cancers: casecontrol study]. Streszczenia z IV Międzynarodowego Zjazdu Naukowego Polskiego Towarzystwa Lekarskiego, Poznań 27-29.06.1988.

23. Zatoński W, Tyczyński J. Otolaryngeal cancer in Poland analysis of epidemiological situation. Materiały z IV Sympozjum Sekcji Onkologicznej PTOl pt. Onkologia w otolaryngologii, Poznań 24-26.06.1988.

24. Zatoński W, Lissowska J, Przewoźniak K. Rola tytoniu w etiologii nowotworów złośliwych krtani [Tobacco smoke in the etiology of laryngeal cancer]. Streszczenia z Sympozjum Polskiego Towarzystwa Onkologicznego pt. Tytoniozależne nowotwory złośliwe, Kraków, 16-17.05.1990.

25. Zatoński W, Becher H, Lissowska J. Smoking cessation: intermediate nonsmoking periods and reduction of laryngeal cancer risk. J Natl Cancer Inst 1990; 82 (17): 1427-1428.

26. Zatoński W, Lissowska J, Przewoźniak K. Rola tytoniu w etiologii nowotworów złośliwych krtani [Tobacco smoke in the etiology of laryngeal cancer]. Streszczenia z Sympozjum Polskiego Towarzystwa Onkologicznego pt. Tytoniozależne nowotwory złośliwe, Kraków, 16-17.05.1990.
27. Zatoński W, Becher H, Lissowska J, Wahrendorf J. Tobacco, alcohol, and diet in the etiology of laryngeal cancer: a population-based case-control study. Cancer Causes Control 1991; 2 (1): 3-10. 28. Zatoński W, Tyczyński J, Didkowska J. Nowotwory złośliwe krtani w Polsce w latach 1963-1989 [Malignant neoplasms of the larynx in Poland in 1963-1989]. Otolaryng Pol 1992; 46 (3): 203-210.

29. Lissowska J, Zatoński W. Nowotwory krtani w Polsce na tle innych krajów Europy. Hipotezy etiologiczne [Laryngeal neoplasms in Poland compared to other European countries. Etiological hypotheses ]. Otolaryng Pol 1992; 46 (3): 211-216.

30. Lissowska J, Zatoński W, Majzel K, et al. Etiologia nowotworów krtani - wyniki badań epidemiologicznych na Górnym i Dolnym Śląsku [Etiology of laryngeal cancer - results of epidemiological studies in Upper and Lower Silesia]. Otolaryng Pol 1992; 46 (4): 350-356.

31. Zatoński W, Zatoński T. Epidemiologia nowotworów złośliwych krtani. W: Rak krtani i gardła dolnego [Cancer of the larynx and lower pharynx]. Janczewski G, Osuch-Wójcikiewicz E (red). Alfa-Medica Press, Bielsko-Biała 2002; 15-29.

32. Rogers SN, El-Sheikha J, Lowe D. The development of a Patients Concerns Inventory (PCI) to help reveal patients concerns in the head and neck clinic. Oral Oncology 2009; 45 (7): 555-561.

33. Kolator M, Mikuła B, Maciejczyk A, Zatoński T. Polish validation of the University of Washington "quality of life" questionnaire in patients with cancer of the larynx. Br J Oral Maxillofac Surg 2019; 57 (3): 226-231.

34. Rogers NS, Alvear A, Anesi A, et al. Variations in concerns reported on the patient concerns inventory in patients with head and neck cancer from different health settings across the world. Head Neck 2020; 42 (3): 498-512.

\section{AUTHORS' CONTRIBUTIONS:}

TZ and EBS prepared the concept of the article. NK, KN and MZ prepared the manuscript. $\mathrm{MZ}$ prepared the historical itroduction. NK, KN, EBS, OF and MK collected the data. EBS and NK processed the data. All authors took part in preparing the final version of the publication. TZ aprroved of the final manuscript.

Stanisław Iwankiewicz was born on November 24, 1920 in Kalisz - the Second Polish Republic. He died on December 15, 2012 in Wrocław - the Third Polish Republic. He was brought up in a family of craftsmen and merchants in Kalisz. He was the youngest of nine siblings. A graduate of the Asnyk humanistic gymnasium in Kalisz, hence his skills and love for writing. Beginning from 1990s until the end of his life, he also began writing poetry. A great organizer with leadership abilities. He carefully documented, described and published his ventures and life events. A very prolific writer.

Wife - Zofia Krystyna was an ophthalmologist. For many years she also sang half-time in the Polish Radio choir. They were married since 1950 and had two sons: Radek and Jarek.

Honorary citizen of the city of Kalisz. Scout, lieutenant-colonel of Polish Army, participant of the Polish September Campaign, soldier of the Home Army (Polish resistance organization during World War II). He participated in the Warsaw Uprising, co-created and participated in the $104^{\text {th }}$ war hospital in the evacuation of wounded insurgents to a camp in Germany (stalag IV B Zeithain in Saxony). Prisoner of Stalag until the end of the war. Decorated with the Silver Cross of the Order of Virtuti Militari.

Due to his origin and military past, after the war he had problems with admission to studies at the Military Medical School, and then also at the civil medical school, and with obtaining a job at the Medical Academy.

Professor of medical sciences, specialist in otolaryngology, Rector of the Medical Academy in Wrocław for two terms (1972-1978). He created the concept, placed it in the state plan, prepared the program and started the construction of a new Medical Academy in Wrocław. When he finished his term of office, the cornerstone was laid for the construction of a new university.

Author of numerous scientific studies and inventions, academic textbooks, books and memoirs.

Stanisław Iwankiewicz was the author of 354 scientific papers, 41 scientific films and 11 rationalization applications. Supervisor of 25 doctorates and tutor of 4 habilitations. He has trained over 40 specialists in otolaryngology.

One of the founders of the Wroclaw Medical School, participated in shaping Polish laryngology. He spent his entire medical life as a laryngologist in the clinic of Medical Academy in Wrocław. Honorary doctorate of the University of Dresden.

Creator and co-founder of the Wrocław Academic Sports Association (AZS) and sports medicine in Wrocław. 